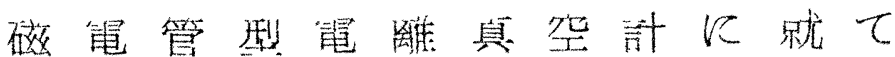

大㕹杖大理工学部兼松太

On the Magnetron Type Ionization Gauge

Futoshi Kanematsu

(Institute of Folytechnics, Osaka, City University)

Calculation and measurements on the cnaracteristics of ion production in a high vacuum cylindrical magnetron were performed. The coincidence between measured and calculated results is tairlygood. The magnetron type ionization gauge offers a goca stability owing to the space-charge saturation sfiect. Tne experimental results indicate a different cnaractoristje from that nbtaineu by Corn and Daglish". In our results the secondary electrons which are proauced accompanying with the gas ionization exnibit a merked effect. It may be consicerod that this effect is related to the Enilips gruge type discnarge.

$\$$

円筒嘫笔管の静的飽和架間電荷状絜の下で行われる残留気体のイオン化につんて、それが

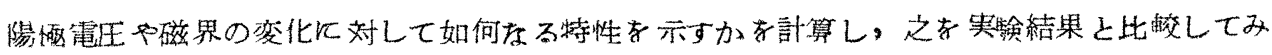
大。之以磁笔管型の笔離真空計の研究上必要な事は勿硢であるが，一般に磁界を用いて電子

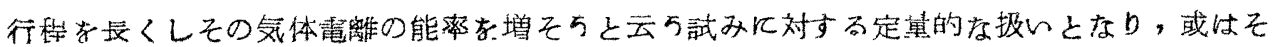

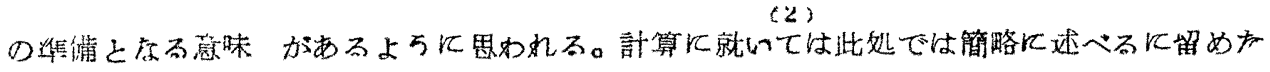
no

々 2 計算及びその姞果に就て

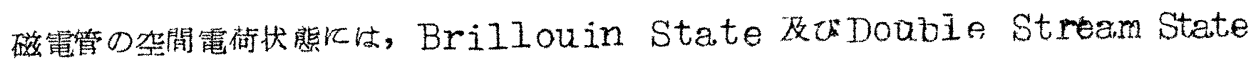
之称される二つの型が可能であり，之等恃夫火第1図の（a）及び (b)に示されス如き笔子 


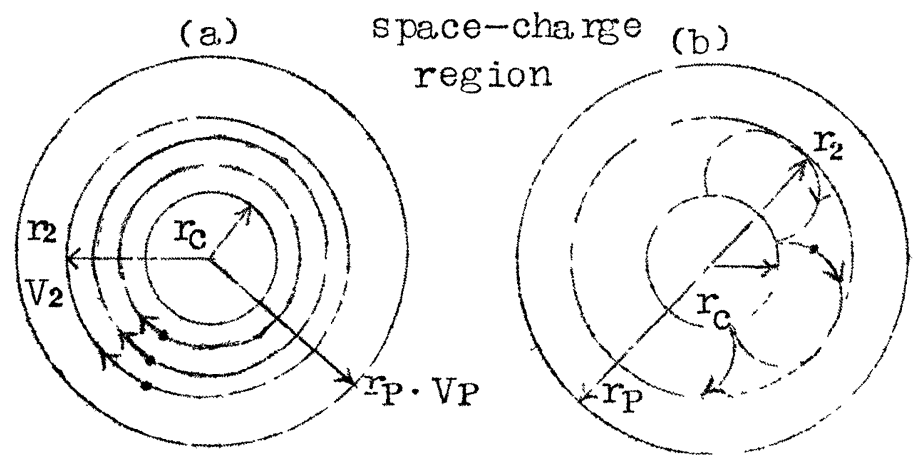

第1図。(a)Brilioun State

(b) Derible Stream state

(3)(4)

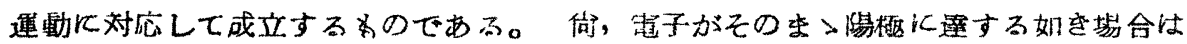

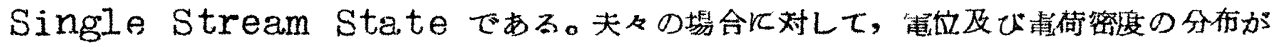
知られるならば，イオン発生量を計算する事が叮能となる。

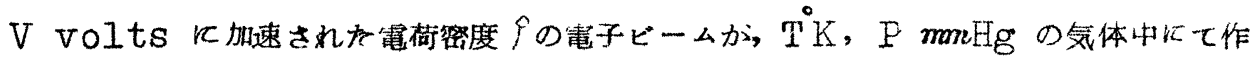
るイオンの数は，単它体皘中と每秒当り

$$
\frac{P}{e} \sqrt{\frac{2 e V}{m}} S(V) P \frac{T_{0}}{T}
$$

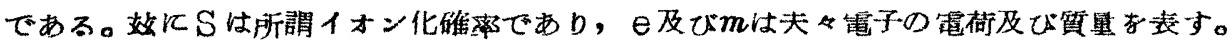

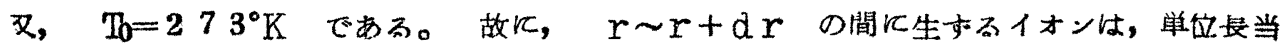
b铂秒

$$
d \mathrm{~N}_{i}=2 \pi \sqrt{\frac{2}{\mathrm{e} m}} \mathrm{~F}_{0} \rho(r) \sqrt{\mathrm{V}(r)} \mathrm{S}(\mathrm{V}) \mathrm{r} d r \ldots \ldots(2)
$$

但し， $\mathrm{P}_{0}=\mathrm{PT}_{0} / \mathrm{T}$ ， と表わされる。

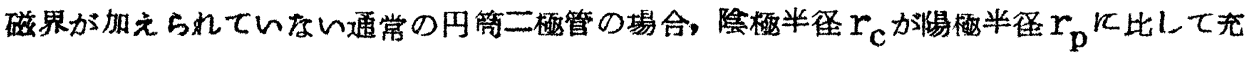

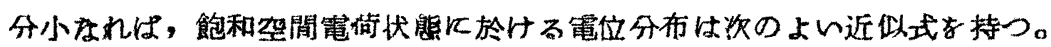

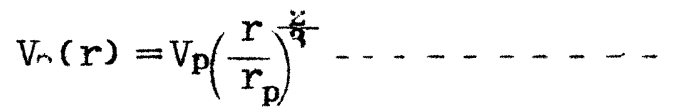

之に対する電荷密度分布は次の如く得られる。

此の蔧合に於ける全イオン発生数は

$$
\rho(r)=\frac{4}{9} \varepsilon_{\frac{V_{p}}{r_{p}^{2}}}\left(\frac{r_{p}}{r^{m}}\right)^{4 / 3}
$$

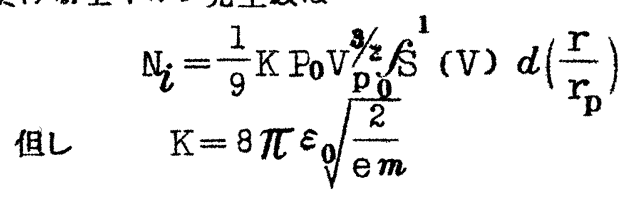




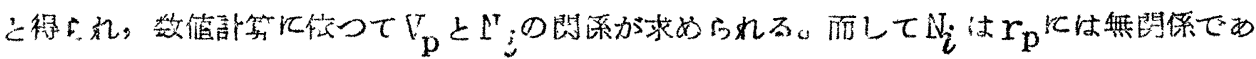

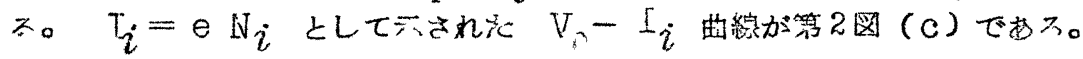

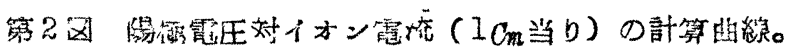

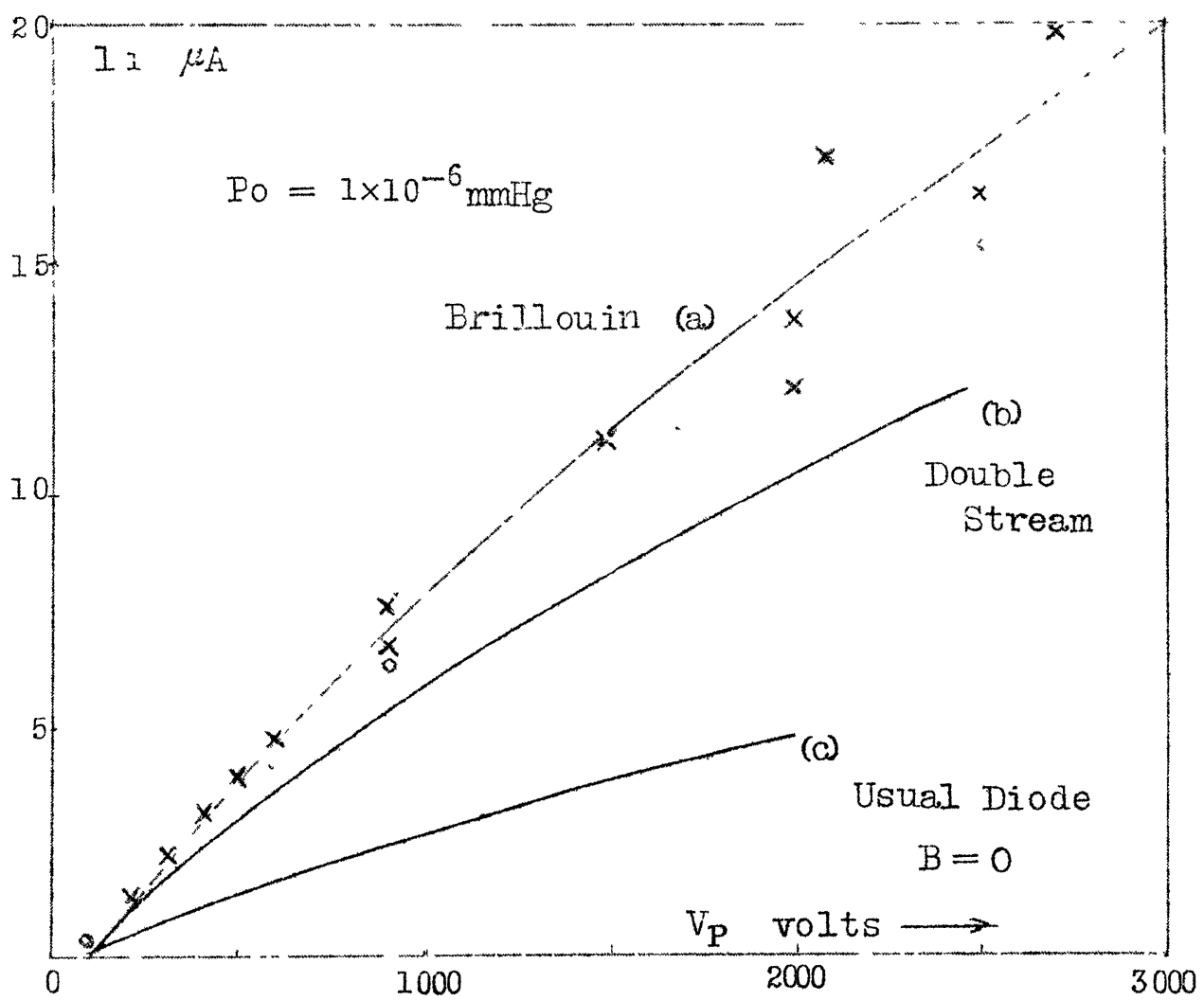

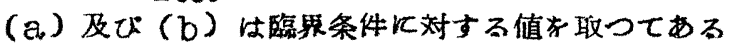

$x:$ 第7図のタマのコレクター筃流測定値

O：第4図

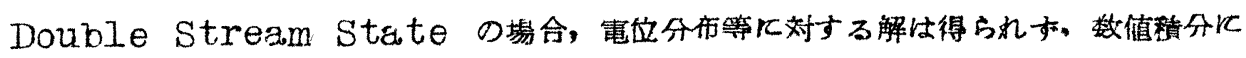

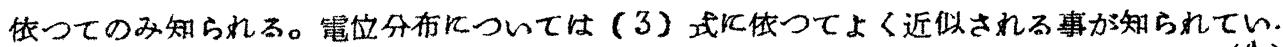
ふが，電何密度分布は（4）式の様なるのではない。それ故效值皘分の結果を参考上しで，

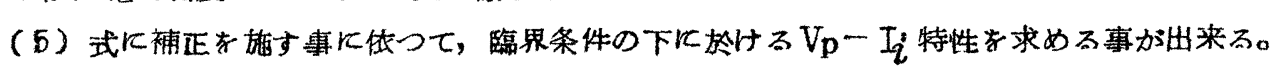

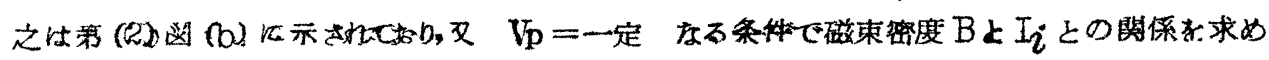

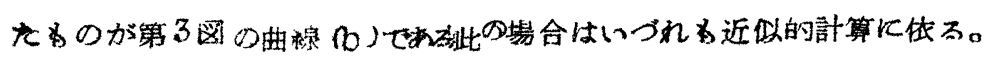

Brillauin State 几於けス電位等の分布式は次の如くである。

$$
V(r)=\frac{e B^{*}}{8 m} r^{2}\left(1-\frac{\dot{r} \vec{c}}{r^{2}}\right)^{2}
$$




$$
\rho(r)=\frac{\varepsilon_{0} e B^{2}}{2 m}\left(Y+\frac{r_{C}}{r^{4}}\right) \cdots \cdots
$$

之等を(る) 式不入れ, B绡去し, 且つ $r_{\mathrm{c}}=0$ と兒做す近似を取れば

$$
N_{i}=K_{0} \frac{3}{2}<\int_{0}^{\prime} S(V) \frac{r^{2}}{r_{i}} d\left(\frac{r}{r_{2}}\right)
$$

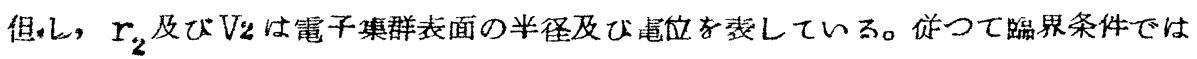
$r_{i z}=r_{p}$ であり，そつ条件で $V_{p}-I_{2}$ 特性を求めると第2爫（a）曲線となる。页， $V_{p}$ 一

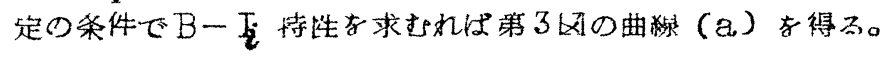

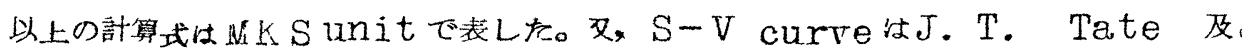

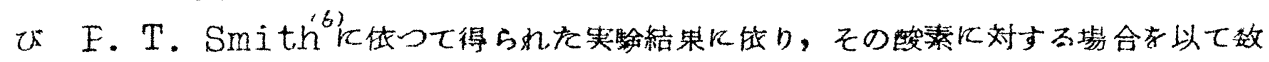

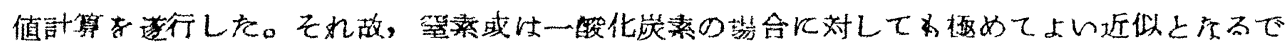

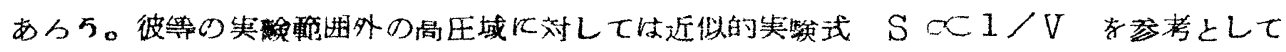
外插したのつ值に依つて計算を行つた。

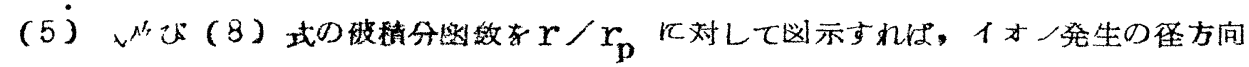

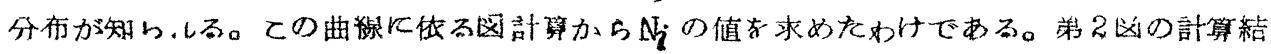

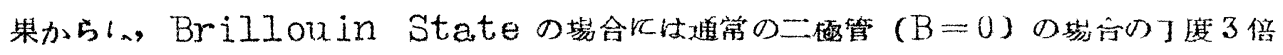
のI，矛られる事が見られる。

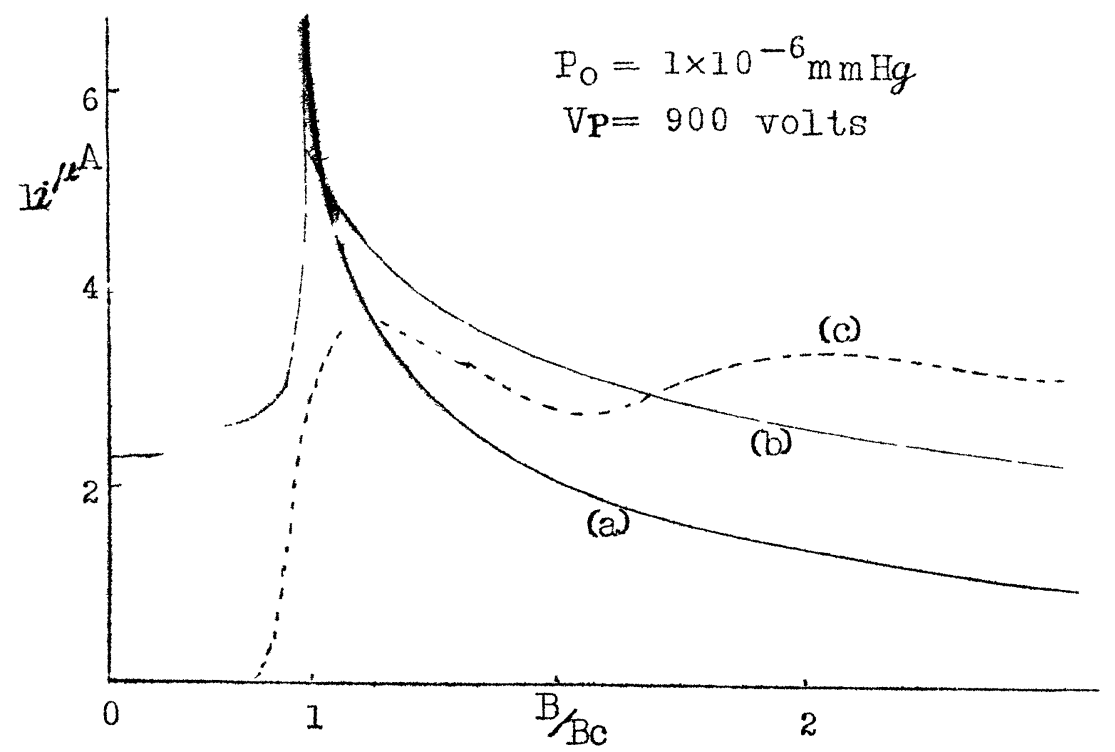

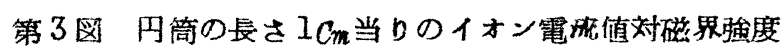

Bcr臨界値。（a) Brillouin Stateの場合,

(b) Double stream State の場合,

(c) 実满曲線，第 5 図上b換算。 


\section{Anode (Mo)}

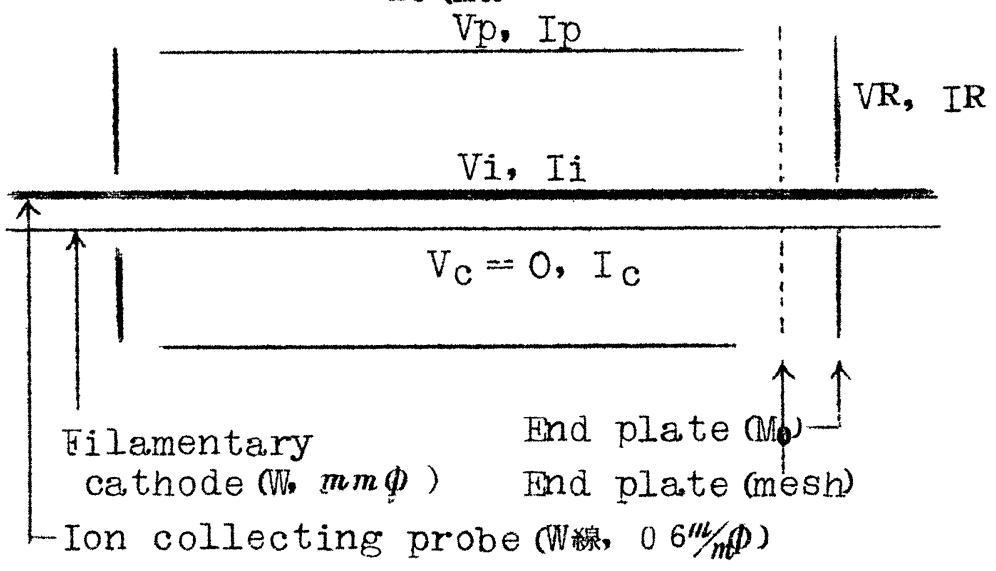

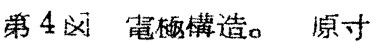

穴了㬰検結果に㩆

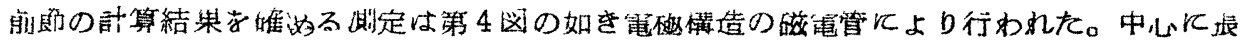

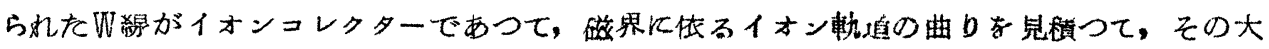

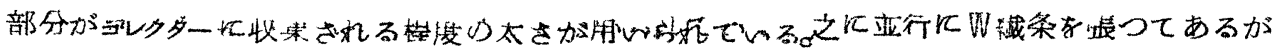

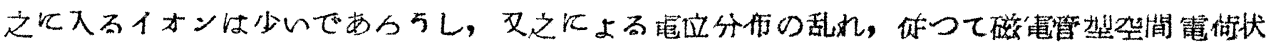

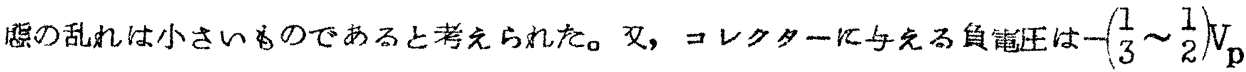

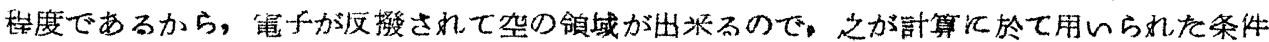

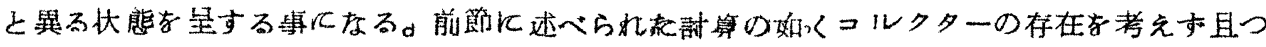

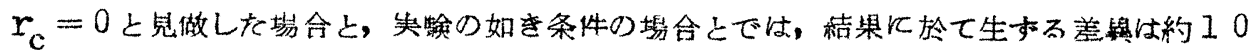
\%程度のタのである事が稚められてある。

使用したンレノイドは, 中心に於て $\mathrm{H}=193 \mathrm{I}_{\mathrm{H}}$ Gauss，中心ょり $3 \mathrm{Cm}$ 略れた軸上の

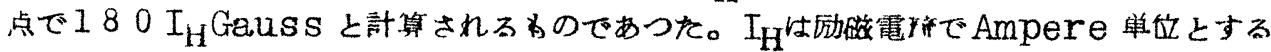

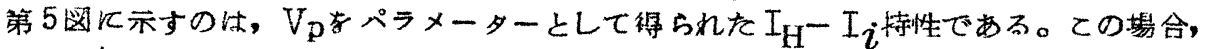
$V_{\mathrm{R}} \doteqdot-\frac{4}{9} V_{\mathrm{p}}$ なる条件が保えれている。この測定結果を計算された $B-I_{i}$ 曲線と比較す

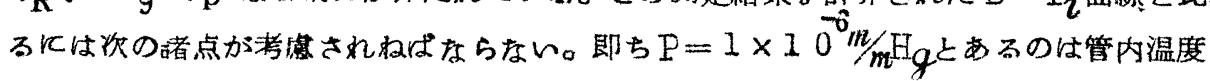

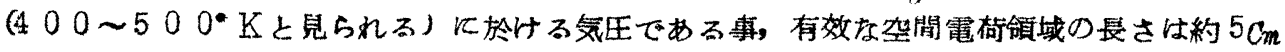

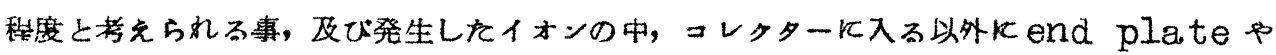

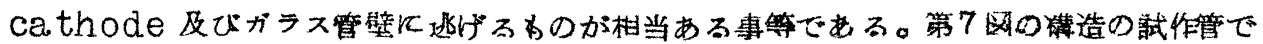
湌討された所ては，コレタターに入るの㤬発生量の略々半分であるので, 第 4 図の試作管

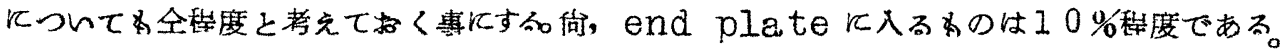

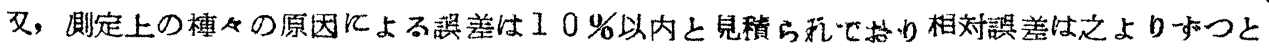


小さい"

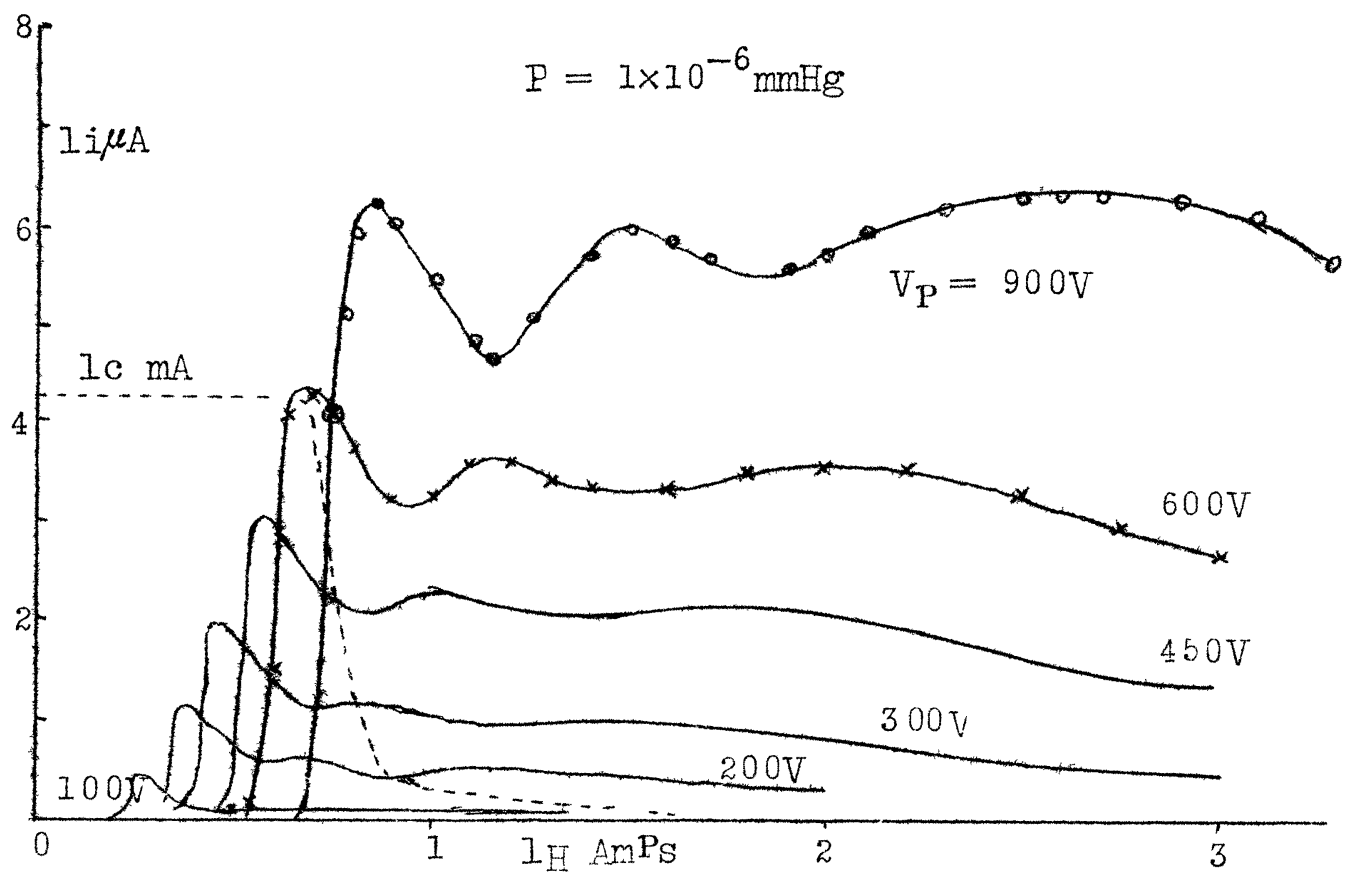

第 5 这 $I_{H}-I_{2}$ 曲線群

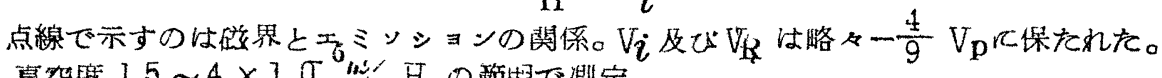

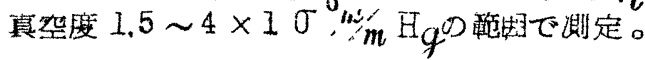

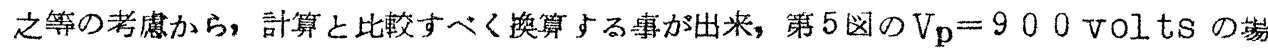
合につき換算された結果を第了图の曲線 (c) 亿示してある。

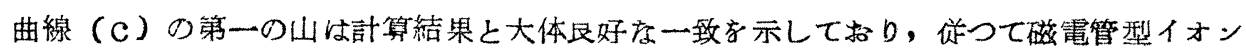

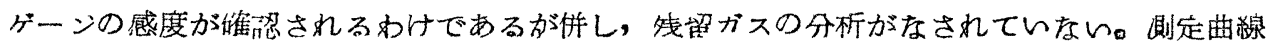
は匴曲線の如く跘いピークは示して拉らす，㳕つてBrillouin 或は Double

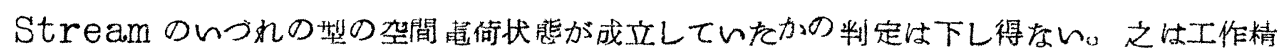
度や磁界の一様性の不足等からして止むを得ない所である。

第3园に於ける比較から分るよらに，それらの曲線のピークの值を以て計算結果との定量

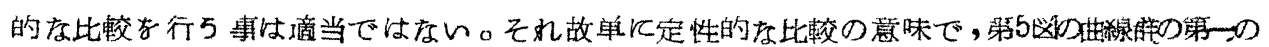

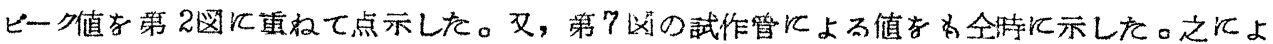

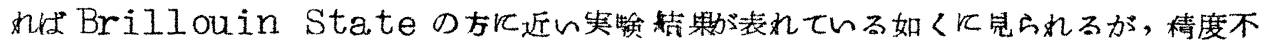

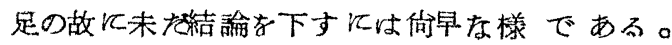

第5図の曲線に現れる第二，茅三の山は，1オ発生に際して生する二次電子に上万效果 であると考えられる。マイクロナンペフ程度の二次電子発生が, 我心の試作管に於て, 気体 


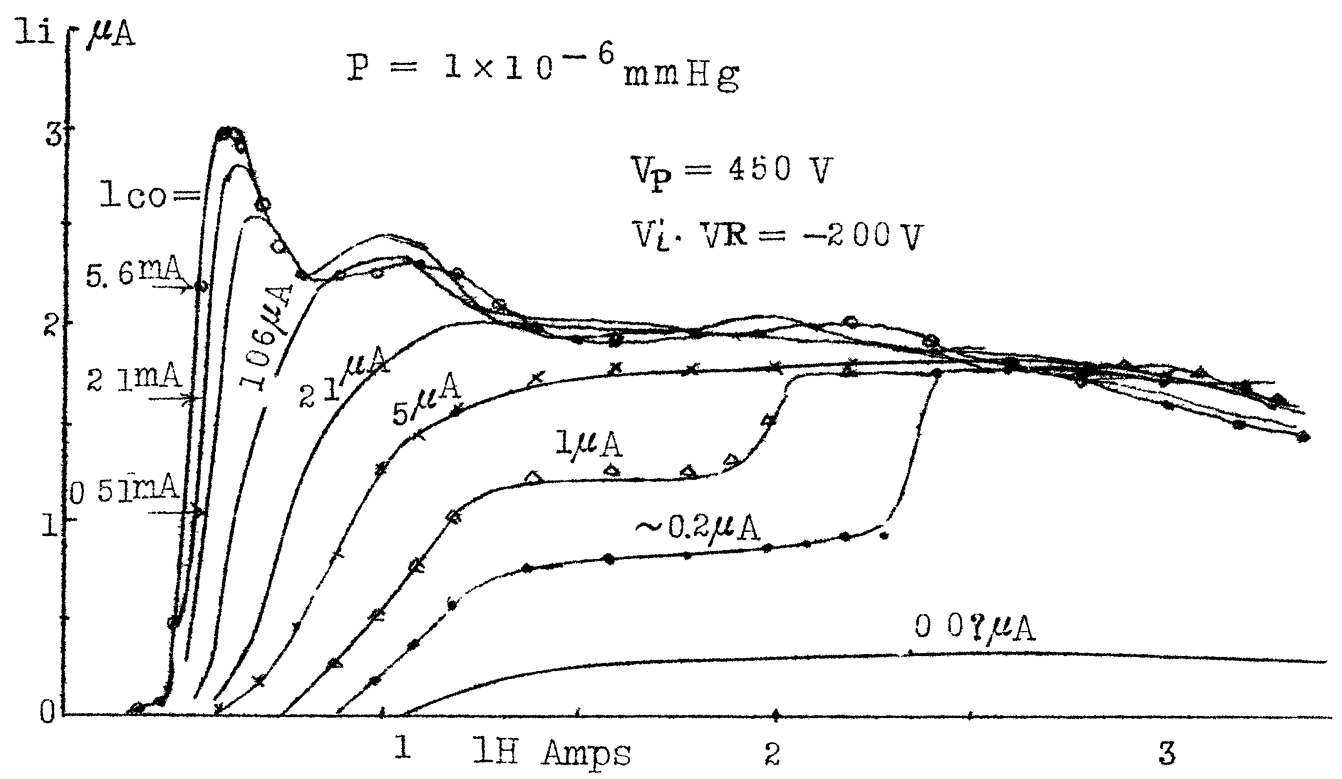

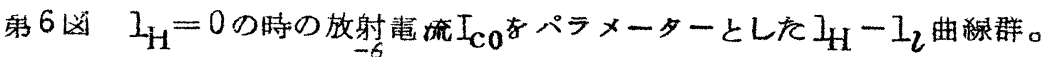
$1.5 \sim 5.5 \times 10^{-6} \mathrm{~m} / \mathrm{m} \mathrm{H}_{\mathrm{g}}$ 真空度にて則定。

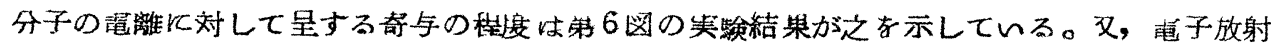

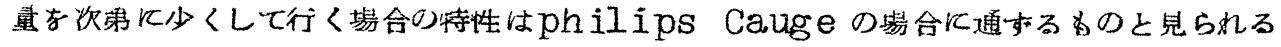
Philips Gauge は実用上は籣单でよいが，動作機模を研究する上には不便な点が多い

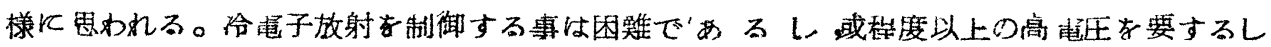

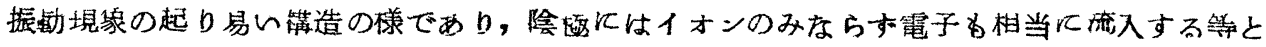

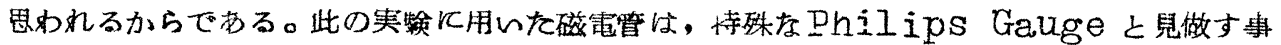
わ出来るので，その基本的なデータ求めるには却つて便利ではあるまいか。

測定上の誤差の原因としては, 実梌されるタ㫑らのガス放出, 或はその呈するクリー二

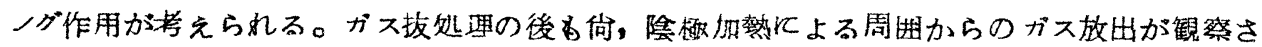

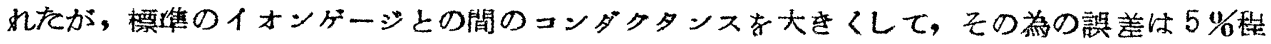

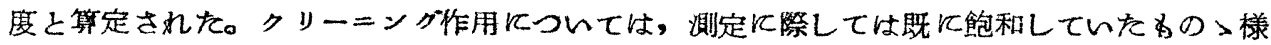
で、観察にかつらなかつた。第7図のタマによる实呀に関しても全様であるが此の方の誤 差は約 $10 \%$ 到石部分事存する。 Ion coIlector

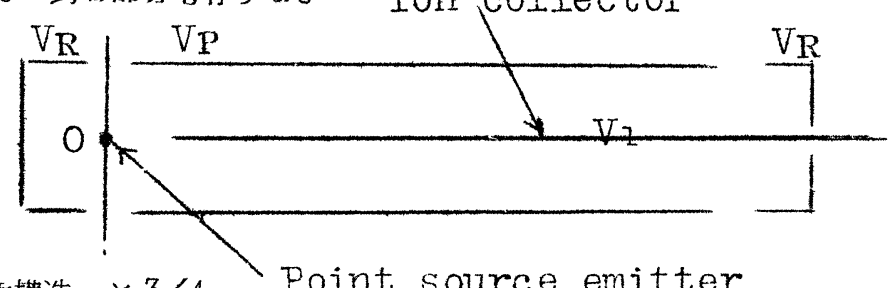

第7 図 電極橉造 $\times 3 / 4$ Point source emitter 


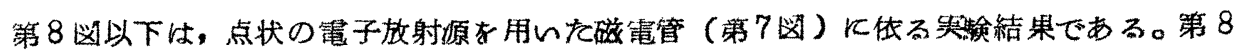

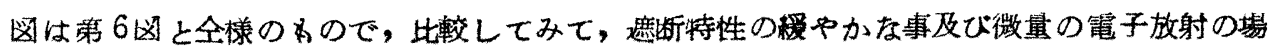
合の持性が巽る点が知られる。

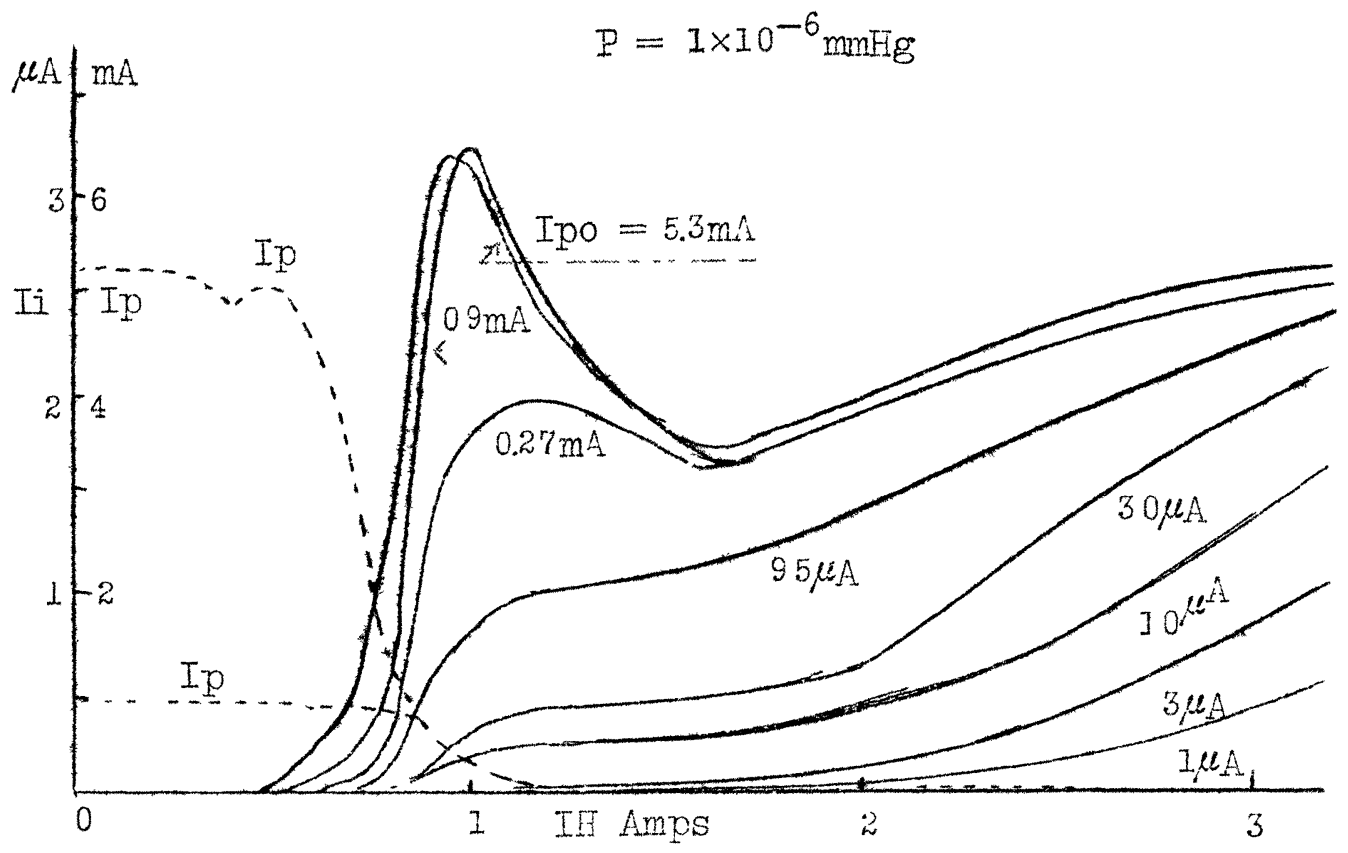

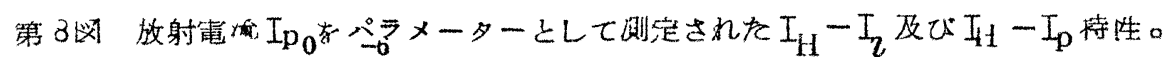

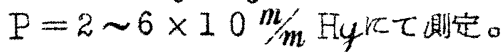

$\mathrm{V}_{\mathrm{p}}=450 \mathrm{~V}, \mathrm{~V}_{2}=\mathrm{V}_{\mathrm{R}}=-150 . \mathrm{V}$

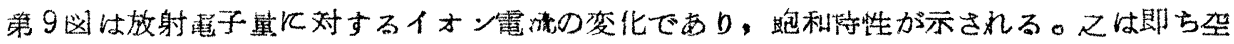

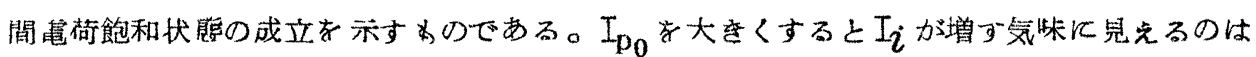

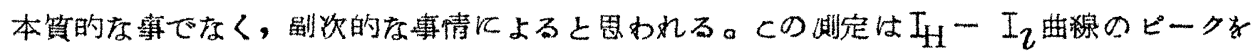
与えス条件で為されたすのである。

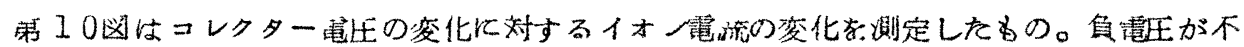

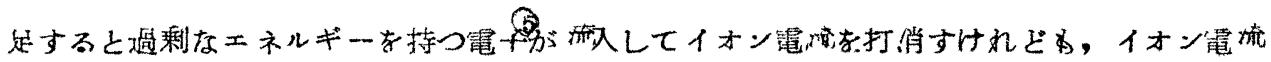

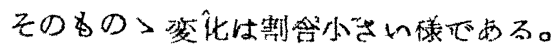

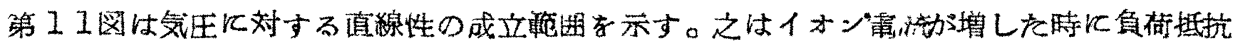

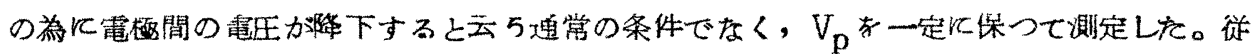
って, Philips Gauge K於けス多くのデータとは, その曲り方が逆である。

第12図に依れば， $V_{p}$ の変化に効しては $I_{i}$ はクリチカルな変化を表さない。 


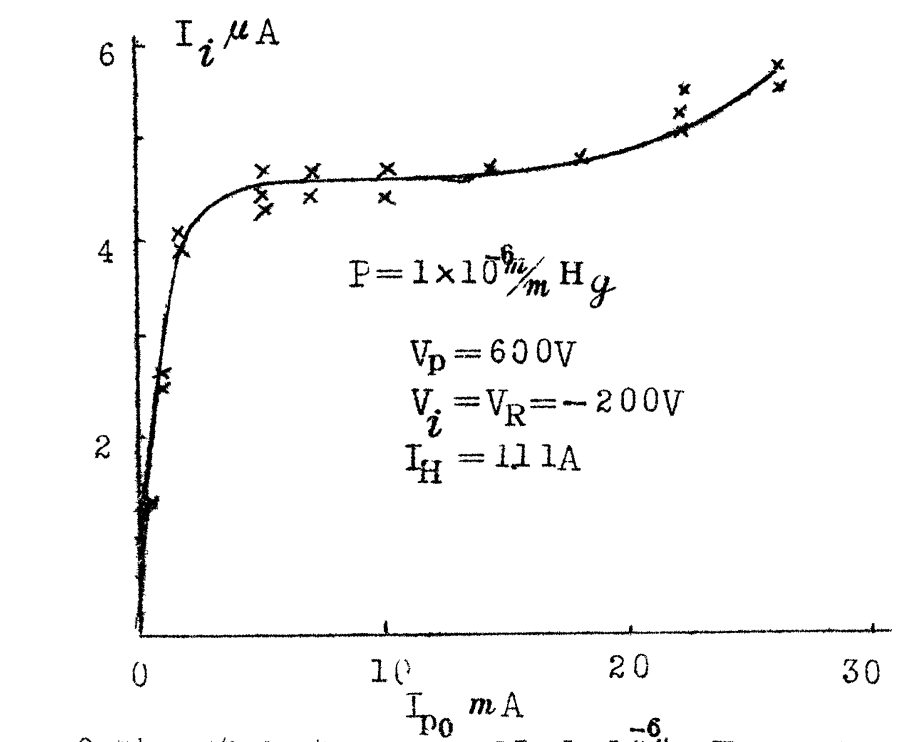

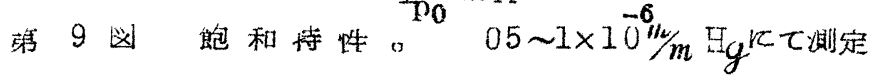

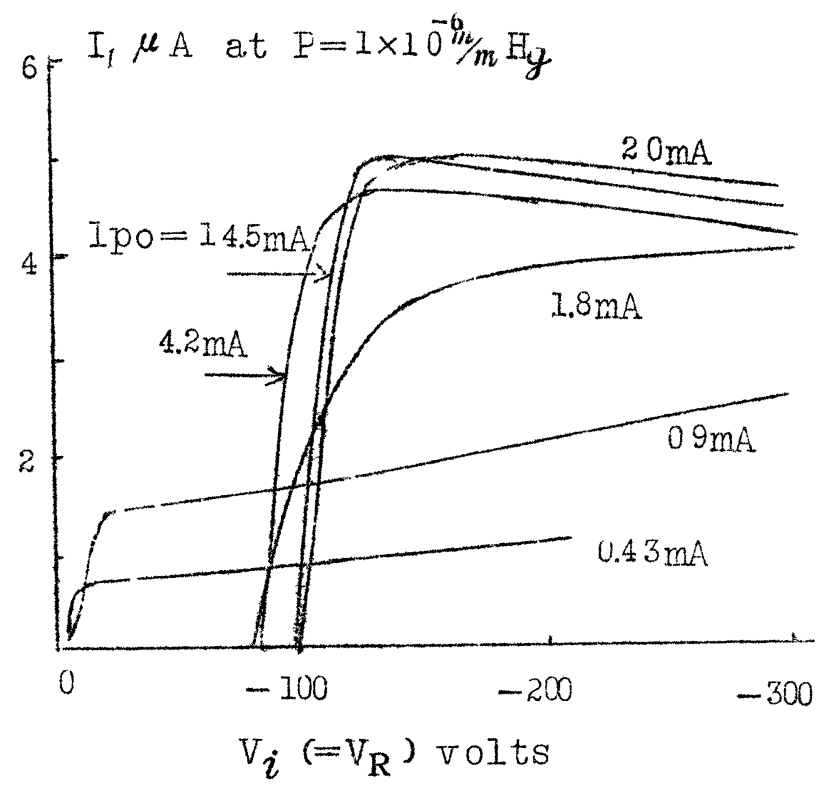

第 10 园 $V_{i}-I_{i}$ 特性。 $V_{\mathrm{p}}=600 \mathrm{~V}, \mathrm{I}_{\mathrm{H}}=1.9 \mathrm{~A}$, $\mathrm{P} \approx 2 \times 10^{-6} \mathrm{~m} / m \mathrm{H}_{\mathrm{q}}$ 测定。 $\mathrm{I}_{\mathrm{p} 0}$ は $\mathrm{I}_{\mathrm{H}}=0$, $V_{i}=-200 \mathrm{~V}$ 時の $I_{p}$ を示す。 


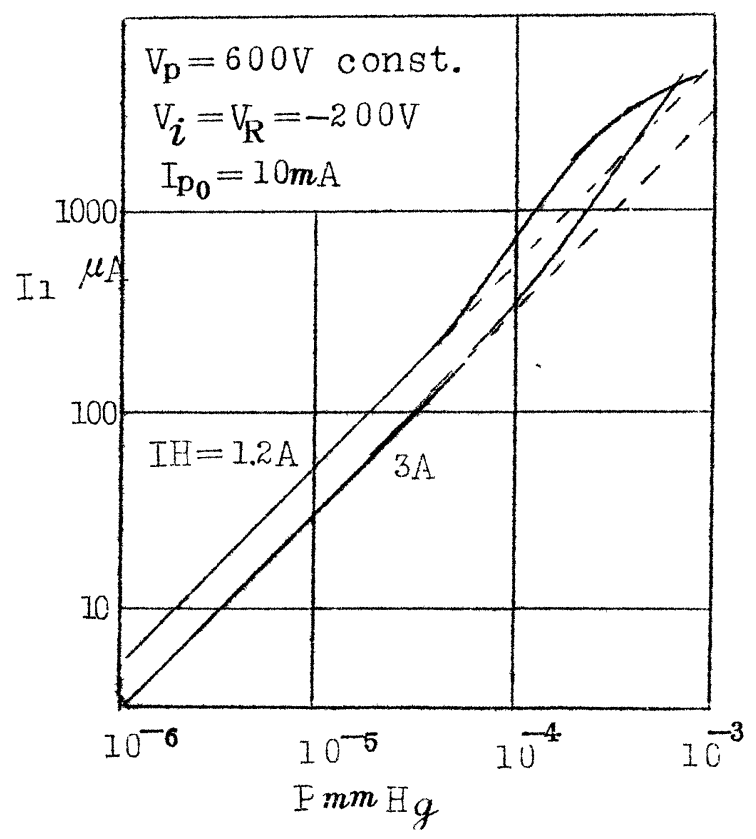

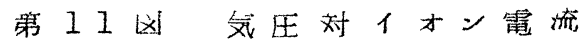

Ii $\mu A$

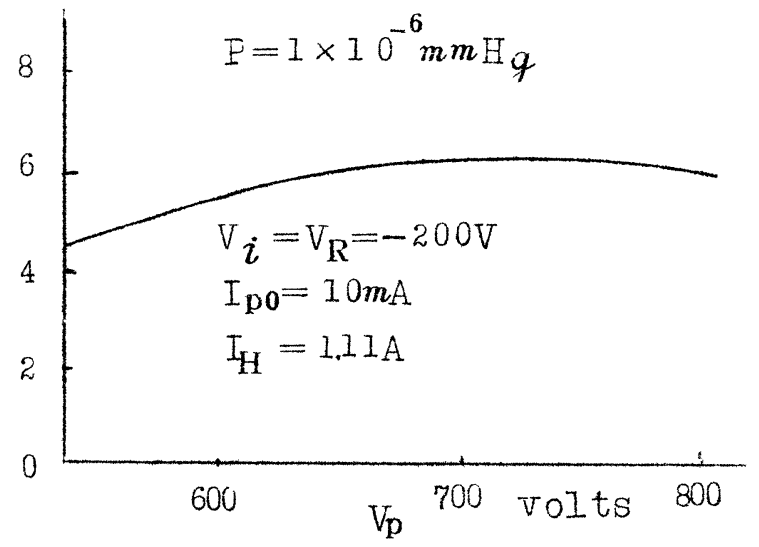

第 12 図'陽極電王対イオ人電流 
$\$ 4$ 結 び

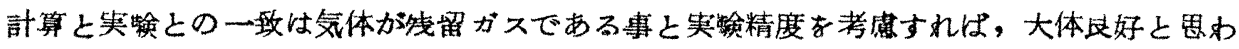
れる。それ故, 此の様な型のイォンゲージの感度の上泿か諗知される。又, その䭂和特性は

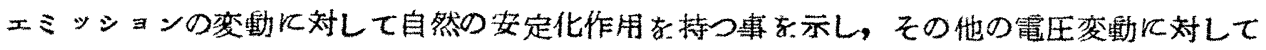

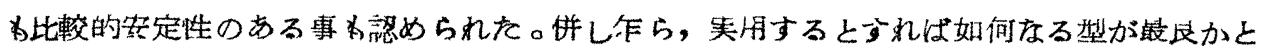

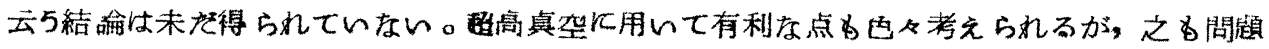
の多い事である。台，計算は暒極の半径には無関係結果を与えるるのであつた。

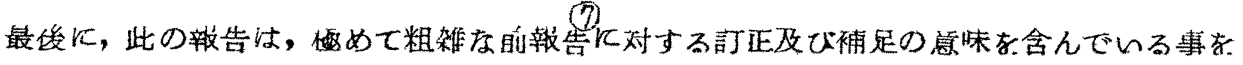
附言させて頂く。

文献

I G. K. T. Conn and H. N. Daglish, "A Thernionic I onization Gauge of High Sensitivity Employing a Magnetic Eield" J.S.I., Vol.31, No. 11 (1954)

2 S. Mi to and E.Kanematsu, "On the Characteristics of I on Production in High Vacuum Cylindrical Magnetron," Journal of the Inst. of Folytech., Osaka City Univ., Vol 3, Series E, (1956)

3 A. W. Hull, "The Effect of a Uniform Magnetic Eield on the Motion of the Ellectron Beam between Coaxial Cylinders," Pryys. Rev. Vol. 18, pp. 31 57 (1921)

4 J.L. Delcroix, "Études des Propriétés statiques des Charges d'Espace du Type Magnétron," Ann. de Phys., Mai-Juin (1954)

5 E.G.Linder, "Excess Energy El ectron and Electron Motion in High Vacuum Tubes," I. R. E., Vol. 26, pp. 346371 , ( 1938 )

6 J.T. Tate and P. T. Smith, "The Efficiencies of Ionization and Ionization Potentials of Various gaus under Electron Impact," Phys. Rev., Vol 39, pp. 270-277 (1932)

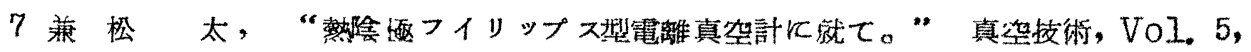
No. 4 (.955) 